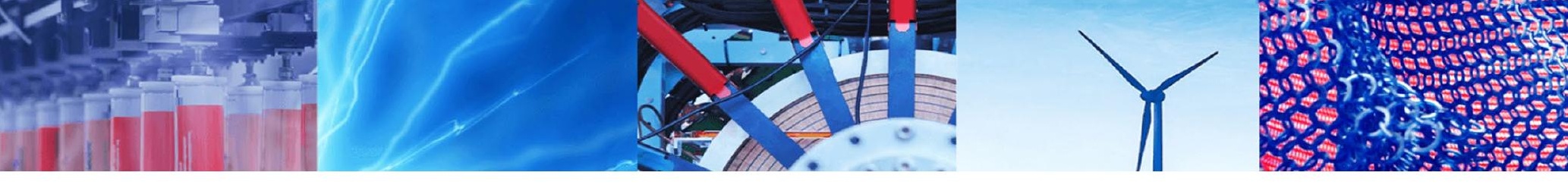

Case Study

\title{
An environmental evaluation of a milling machine range: a case study on reconfigurable approach
}

\author{
Eva Martínez Herrero ${ }^{1}$ - Lorena Pereda Pereda ${ }^{1}$. Fernando Huidobro Fernández ${ }^{2}$. Juan Carlos Monje Pardo ${ }^{3}$. \\ Blanca Urquidi Sandoval ${ }^{3}$
}

Received: 23 May 2019 / Accepted: 22 October 2019 / Published online: 30 October 2019

(c) Springer Nature Switzerland AG 2019

\begin{abstract}
Purpose: The aim of this paper is to describe the adaptation process of the LCA methodology under a modular approach ( $\mathrm{LCl}$ data and LCIA data based on modules) in parallel to a reconfigurable design (reconfigurable manufacturing system) that enables a faster and easier quantified environmental claim for a range of milling machines. Methods: Life cycle assessment (LCA) is identified as a proper tool to evaluate potential impacts of products over the environment. However, the compilation of LCA data from one or a range of milling machines could be difficult and tedious, because, firstly they are complex products, secondly the final results have to ensure a good representability and, finally, render the assessment process cost-effectively. The analysis was performed following a cradle-to-use approach. The LCA study was performed in compliance with [18] V2.0 developed in framework of the EPD ${ }^{\circledR}$ System. Results: The LCA results show that the contribution of downstream processes is the most significant in all studied impact categories, since the relative contributions are: $89 \%$ in the GWP and AP categories and $77 \%$ in the POCP and EP categories, because of the demanded electricity during the lifetime of the machines, with values greater than $94 \%$ of the impact of downstream processes. The upstream processes present a moderate contribution in the POCP and EP categories, being their relative contribution major than $20 \%$ in both of them, because of cast iron $(\approx 60 \%$ in POCP) and low-alloy steel ( $\approx 20 \%$ in POCP) materials which form part of the structural modules as well as pumps and motors $(\approx 40 \%$ in EP). Discussion and Conclusions: The study takes a holistic view of the production and consumption of a milling machine range. The case study presents the adaptation of LCA methodology for a range of milling machines, in order to develop the EPD of these products. Simultaneously the LCA calculation of 28 machine reconfigurations is achieved through 9 modules, thus reducing time efforts and costs. The weakness of the representative check is located in the inventory analysis of the use stage. A future work could include a sensitivity analysis to evaluate more user conditions.
\end{abstract}

Juan Carlos Monje Pardo-Deceased.

Eva Martínez Herrero, evamtz@ctme.es | 1 Fundación Centro Tecnológico de Miranda de Ebro (CTME), Pol. Ind. Bayas R60-61, 09200 Miranda de Ebro, Spain. ${ }^{2}$ Hypatia GNC Accesorios S.A., Calle Condado de Treviño 53, Polígono Industrial de Villalonquéjar, 09001 Burgos, Spain. ${ }^{3}$ MASIDI Ingeniería, Calle Haya 16, Polígono Industrial “Los Brezos”, 09197 Villalbilla de Burgos, Spain. 


\section{Graphic abstract}

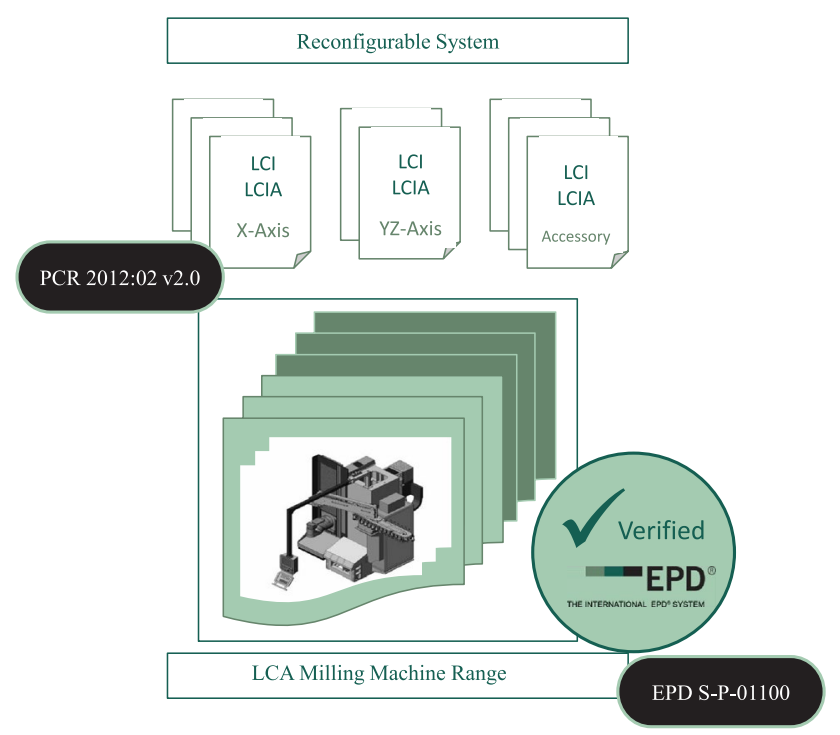

Keywords Environmental product declaration - Life cycle assessment - Product category rules - Machine tools . Milling $\cdot$ Modularity

\section{Background and introduction}

The machine tool industry is a sector where technology is expanded and equated with increasing speed, so the technology factor becomes less relevant as a competitive factor to increase the differentiation of a company in the market [8]. Hence, ecodesign appears as an opportunity to reinforce the uniqueness and differentiation of the product in the market [4]. Also, machine tools fall inside the scope of Ecodesign of Energy related Product (ErP) Directive 2009/125/EC. Machine tools are one of the product groups that have been considered by the European Commission for the establishment of the ecodesign requirements.

The machine tool builders have begun to design optimized production environments with regard to the use of material and energy resources associated with the life cycle of production systems: concept, design, manufacture, use, maintenance, end of life of machine tools and so on $[16,19]$.

Knowledge of the ecodesign methodology and an ecolabel which guarantees specific, objective, complete and unbiased information are demanded by machine tool industry [1].

Life cycle assessment (hereinafter, LCA) is increasingly being used as an objective and credible tool to measure the environmental performances of products and to assess the environmental sustainability of the production chain [24].

The LCA is established methodology for the quantification of product environmental performance and is increasingly being used as a basis for labels and reports that inform clients, business to business (B2B) approach, and consumers, business to consumer (B2C) approach, in the supply chain [6].

However, the compilation of LCA data for complex investment goods, such as machine tools, solely on the basis of ISO standards or similar could encourage the misuse of the concept of LCA, and add ambiguity to this kind of studies [21]. LCA methodology requires that the author has to make many choices regarding the declared unit, boundary, the source of data, allocation between different products o co-products, etc.

There are a number of requirements regarding how the LCA model should be performed to be used as basis for an environmental product declaration (hereinafter, EPD). On the other hand, reconfigurable manufacturing system (RSM) is one that is designed at the outset for rapid change in its structure, as well as in its hardware and software components, in other to quickly adjust its production capacity and functionality, within a part family, in response to market changes [13]. Modularity is a key characteristic of reconfigurable machine tools (RMT) [22].

The aim of this paper is to show the adaptation of LCA methodology to a milling machines range (NORMA Range under CORREA trademark), in order to develop Type III environmental declarations (hereinafter, EPDs) based on environmental information modules associated with the inventory $(\mathrm{LCl})$ and the assessment $(\mathrm{LCIA})$. The environmental information modules are LCA-based information for parts, components and other inputs that are used to manufacture or assembly of milling machines.

Environmental impacts of machine tools over the whole life cycle have been studied; CECIMO (European Association of the Machine Tool Industries and related Manufacturing Technologies) carried out in 2009 a LCA over nine machine tools from five companies of two types of machine tools milling and turning machines. The LCA concluded that the most significant environmental impact of machine tools occurs during the use phase compared to other phases such us, construction, transport installation and dismantling [7]. [14] developed an enabling webtool to perform a sector specific life cycle based on environmental assessment. It provided tailor-made solutions to integrate simplified life cycle approaches into daily business process in machines tool sector.

Additionally, some studies have investigated the optimal machining parameters to more sustainable production system, $[2,17]$. 
The novelty in the study is related on green chain management. This paper describes activities related with life cycle thinking focused on supply chain perspective. NORMA, bed-type milling reconfigurable machines range is the first case study of integrating environmental labelling Type III into metalworking supply chain.

\section{Methods}

The International EPD ${ }^{\circledR}$ System (www.environdec.com) offers an international environmental information tool, General Programme Instructions for the International EPD $^{\circledast}$ System v3.0 (2017) [hereinafter, GPI [5]], adaptable to any organization that wants to disseminate quantified and verified environmental information of their products, in a credible, comparable, simplified way.

Product Category Rules (hereinafter, PCRs) provide category specific guidance for estimating and reporting product life cycle environmental product declarations and product carbon footprints [25]. PCRs offer some distinct benefits: greater consistency and comparability of assessments based on the same rules; modularity of assessment scope; transparency of requirements and in the development process; guidance and clarity to users undertaking assessments within product sectors; and flexibility of use by any entity.

As aforementioned the main goal of this study was to quantify the environmental performance from NORMA, bed-type milling reconfigurable machines range. The analysis was performed in compliance with the [18] v2.0 developed in framework of the International EPD ${ }^{\circledR}$ System. The target products can be classified within class 44214 entitled "Machine tools for drilling, boring or milling" [3]. This PCR is a huge step forward towards unambiguous guidance, regarding how data should be calculated (via its definition of background data for upstream processes, system boundaries, cut-off criteria, function unit, etc.) [21].

The major objective of the instrument [18] v2.0 is to give pragmatic and relevant guidance to LCA practitioners, milling machine builders and users of milling machines on how to move forward in the field of LCA towards comparative, meaningful study results. The protocol [18] v2.0 clarifies aspects that are not totally consistent or could encourage the misuse of the concept of LCA.

In particular, Hypatia GNC Accesorios S.A. collected necessary data to complete the life cycle inventory of 28 milling machine reconfigurations under a modular scope. Machine tools are usually designed in a modular way in order to reduce downtime of the machine in case of problems. Furthermore, modularity allowed the assembly of LCA impact assessments of parts and components which serve as inputs to the milling machine systems, as shown in Fig. 1. Based on the underlying LCA study [15] according to the ISO [9-11] series of standards, an environmental declaration of product was performed for 6 structural modules and 3 accessories, 8 standard configurations and a total of 28 reconfigurations have been environmentally assessed [23].

\section{Calculation and results}

The analysis was performed following a cradle-to-use approach, taking account all the activities involved from production of raw materials for main parts and components to lifetime operation, including power losses and emissions. Special efforts had been made in the evaluation of the use phase scenario, performing experimental measurements of electrical energy consumption for different operating modes, as well as in the identification of considered/not considered processes in each stages of cycle of life and in the selection of primary data (specific data for process and/or enterprise) and secondary data (database) used in the LCA.

\subsection{Declared unit}

One milling machine at builder's factory gate, excluding end of life milling machine, was selected as DU for calculations which in agreement with [18] v2. Environmental information modules are used to define and assess the milling machine (final product). In this case study, scale 1:1 is applied, to the reference flow of the final product.

The reference flow between the physical unit and the operative unit shall be related to the lifetime. In the

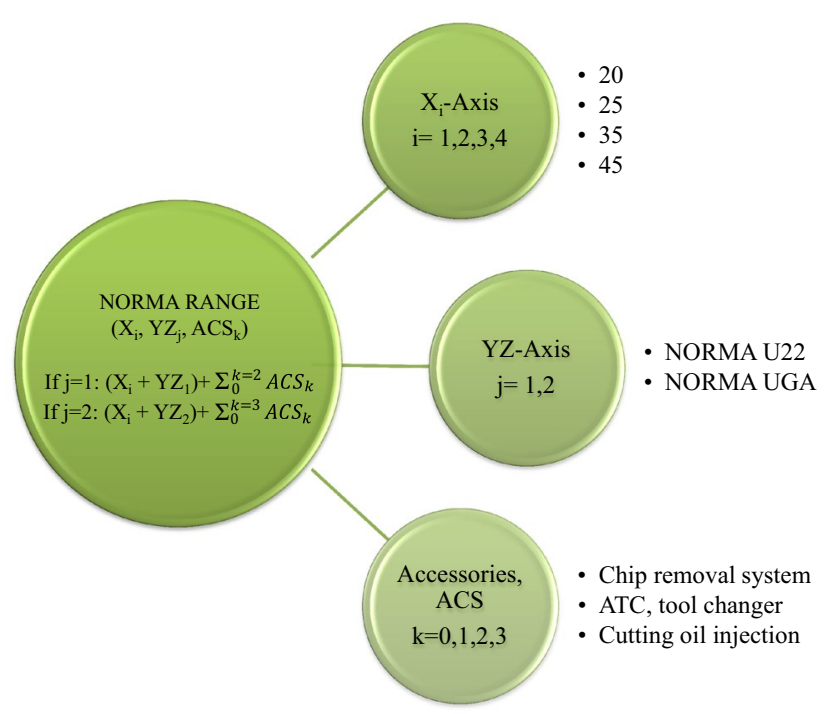

Fig. 1 Level of reconfigurability. Modular machine subsystems 
underlying LCA, a family of bed-type milling machine equipped with a horizontal ram and numerical control, useful for the sector of dies and medium-sized moulds and for the general mechanics sector, was studied. The reference flow has been defined as a lifetime of 15 years according to the cumulative time diagram of Fig. 2 . The cumulative time diagram indicates fractions of time during which different machine tool activities or functions can run: The product life in years is showed and a representative use pattern is reflected. These functions cover the vast majority of machine tools in a generalized view, and they are independent from the design each machine tool. Table 1 describes each generalized function.

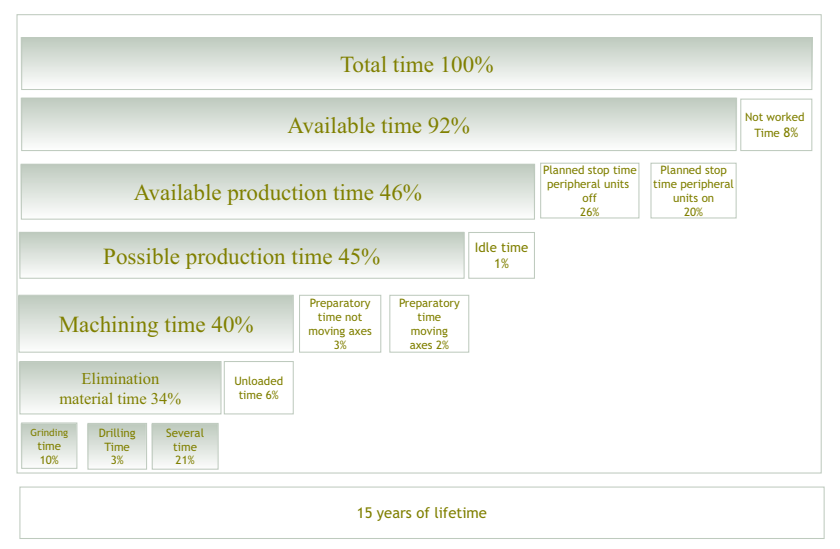

Fig. 2 Cumulative Time Diagram (CPC 44214 v 1.0, 2012)

\subsection{System boundaries}

The life cycle boundaries for milling machines are described in the flowchart of Fig. 3. The system boundaries must be established following general supply chain logic, covering the entire life cycle. The system boundaries were defined with respect to builder of milling machines, so the use phase is included in downstream processes.

The upstream stage represents the raw materials which come into the factory and includes the inflow of raw materials and their manufacturing processes, as well as commercial components such as motors, pumps, etc. The most used material in the product "milling machine" is cast iron, which stands for more than half of its total weight. Low carbon steel pieces reach around $20 \%$ of machine weight. Secondary processing of materials are standard production processes: extrusion, injection, milling process, bending process, etc. [23]. Transport of raw material from the most direct supplier to the builder's factory shall be included.

In general, the transportation mode (in tonne-kilometre) is based on distance from the supplier to the manufacturing plant and the amount of goods. In the case study, the transport processes are evaluated using the corresponding dataset of ecoinvent 3.3 [26].

The core processes represent the operations which are made in the builder's factory and include the manufacture and the assembly of the product parts. The main production processes to manufacture milling machines

Table 1 Definition of split time intervals (CPC $44214 \mathrm{v} 1.0,2012)$

\begin{tabular}{|c|c|}
\hline Time & Definition \\
\hline Lifetime & $\begin{array}{l}\text { The total time of net theoretical production of a milling machine during its life, if the suggested maintenance } \\
\text { schedules are followed }\end{array}$ \\
\hline Total time & The continuous time interval during which the performance of the equipment is considered \\
\hline Not worked time & The time interval during which the equipment is not used \\
\hline Available time & Time scheduled for production, from start of shift to end of shift \\
\hline Planned stop time & $\begin{array}{l}\text { Cumulative time interval during which there is a scheduled stop. It is the sum of the time spent in the prepara- } \\
\text { tion, after production and planned maintenance phases }\end{array}$ \\
\hline Available production time & $\begin{array}{l}\text { The time during which the equipment could have performed a required function if an unplanned stop would } \\
\text { not have occurred }\end{array}$ \\
\hline Idle time & $\begin{array}{l}\text { Cumulative time interval from the moment the equipment becomes idle to the moment it returns to the same } \\
\text { state it was before the stop }\end{array}$ \\
\hline Possible production time & The time period during which the equipment could have performed a required function without stops \\
\hline Machining time & $\begin{array}{l}\text { The time during which the equipment performs its primary required function: material removal and axis mov- } \\
\text { ing without any contact with the pieces }\end{array}$ \\
\hline Material removing time & The time during which the equipment applies cutting force \\
\hline Grinding time & $\begin{array}{l}\text { The time during which machining is carried out on the previously machined bloom to achieve the desired } \\
\text { surface finish of the workpiece. That it is to say, the machined bloom is flattened to obtain a surface finish } \\
\text { with the allowable tolerance. Milling head works at } 75 \%\end{array}$ \\
\hline Drilling time & The time interval during which holes are bored in bloom by cutting edges (diameter 20 mm/depth $60 \mathrm{~mm}$ ) \\
\hline Several time & The time during which semi-finishing and finishing operations are performed (milling head is running at 15\%) \\
\hline
\end{tabular}




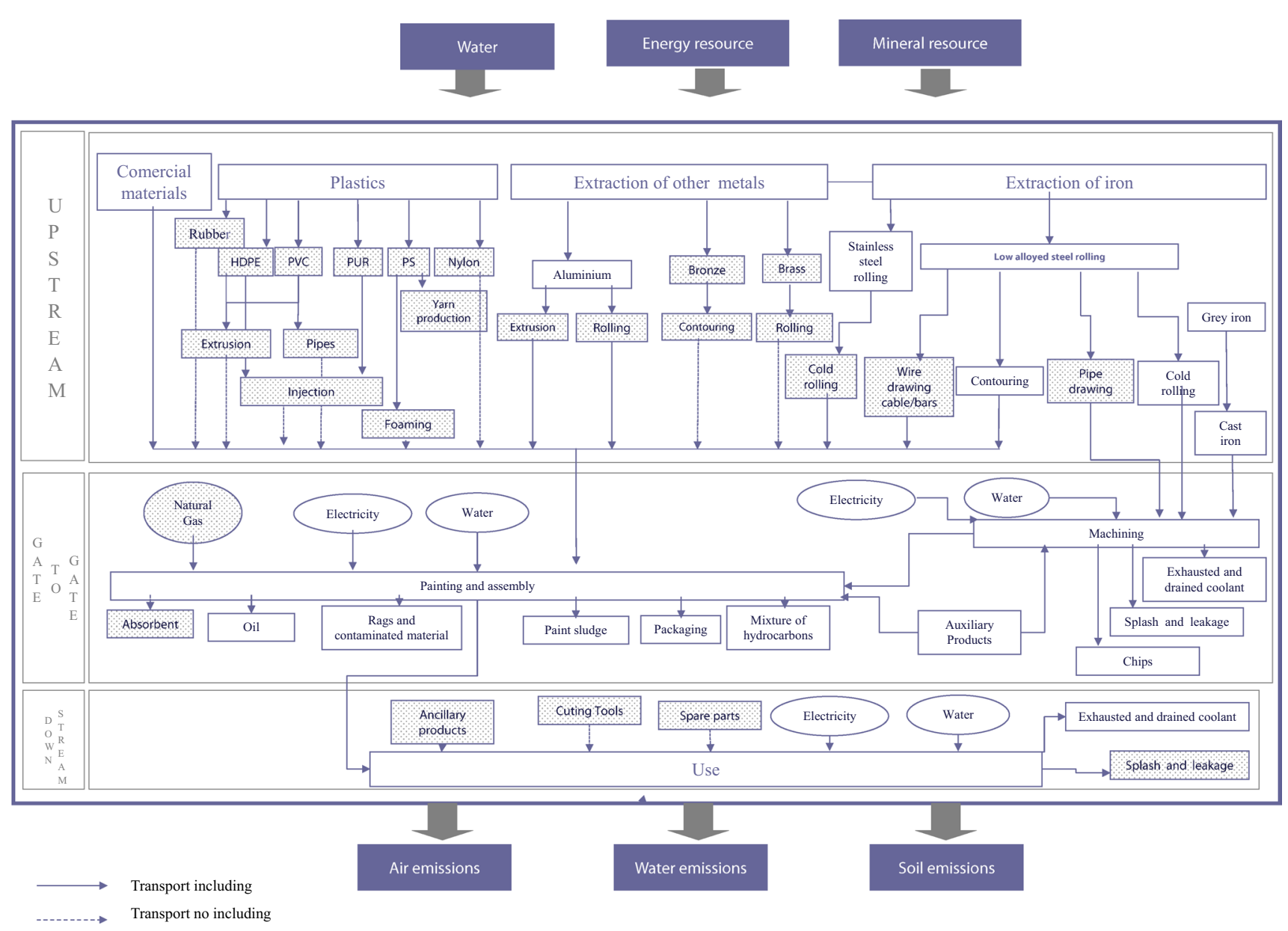

Fig. 3 Flow chart of system boundaries of the product system of NORMA milling machine range

are typically metal working processes: drilling, cutting, bending, etc. performed on metal working machine tools, assembly processes and surface treatment processes, as surfaces of machine housing are typically colour coated. External transportation of ancillary materials, e.g. paints, cutting oils, etc. from the most direct supplier to the factory and internal transportation within the factory shall be included, e.g. pieces to be milling, as well as waste transportation from the builder's factory to the authorized residues manager's factory. The processes stages for all machine modules are produced on the same production plan.

The downstream processes represent the use and the end of life stages of machine and include transportation from the factory to the customer site, lifetime operation of the product (electricity and consumables), maintenance and replacements of parts during lifetime.

\subsection{Cut-off rules}

Life Cycle Inventory (LCI) data for a minimum of $99 \%$ of total inflows and outflows (based on mass, primary energy and environmental impacts categories) are included. And all the chemicals or substances are classified as hazardous for health or environment, carcinogenic, mutagenic or toxic for reproduction (chemicals or substances with R-phrases or Risk phrases) that are present in a concentration that requires labelling in accordance with Regulation (EC) No 1907/2006. Iterative nature of LCA requires to review one or more times the contribution of each flow and manage accordingly the data collection, the impact assessment, etc. A readjustment was made to ensure that $99 \%$ of flows are declared, so values of less than 1 (based on mass, energy and environmental impact) were considered. In Fig. 3, the shaded flows are not included in the 
EPD because they are processes that together add up less than $1 \%$ of mass, energy and environmental impact for each impact category.

In order to add transparency to the LCA study, chemical preparations applied in the process are identified, as well as and the concentrations of substances present in these preparations according to their material safety data sheets (MSDS). Due to lack of specific databases, substances had to be assimilated to another similar one (in molecular structure or functional groups).

\subsection{Allocation rules}

In principle, avoiding allocation is recommended by the ISO standard [10]. However, the system under evaluation can be considered as a typical multi-output system where allocation is not avoidable. For machine tools, the allocation problem focuses on core processes, where the system under study interacts internally and with other product systems, e.g. the machining or the painting of the different structural modules and accessories, or of other pieces that are not part of the analysed equipment. Consistently, working hours were taken into account as allocation criteria.

\subsection{Data quality rules}

Specific data (or primary data) shall be used for the Core Module. Specific data are data gathered from the sites where specific processes are carried out. The requirement for specific data also include actual product weight, amounts of raw materials used, amounts of waste, onsite generation of steam, heat and electricity if relevant, etc. Spanish power grid mix was used for the electrical demands of the Gate-Gate stage.

In downstream process, a special emphasis is placed on electricity demand of the usage stage because it is a major contributing factor to pollutant emissions as potential environmental impact. A global electricity profile was used, such as a generic scenario for comparison purposes (Electricity, low voltage $\{\mathrm{GLO}\} \mid$ market group for | Alloc Rec, U, 2016).

\subsubsection{Electricity consumption scenarios during the use phase}

Electricity consumption during the use phase of the machine tool is closely linked to productivity, availability and/or accuracy [20]. The use of these machines is related to the variability of applications in productive environments, demanded by the users themselves, e.g. machine shops, industrial plants, number of working shifts, integration (single machines or automated production systems), control systems (mechanical or automated), power systems, manufacturing methods, etc. The evaluation of "typical" use patterns are challenging due to the very different machining cycles in manufacturing processes, so the large number of patterns include from one or more operating shifts to permanent or occasional use.

A cumulative time chart and experimental measures should be conducted to study the environmental impact of the use phase of a milling machine. An absolute estimated value of electricity is obtained as a weighted average of the experimental measurements of electricity consumption in different production modes (productive and non-productive) through a cumulative time diagram. Figure 2 shows the temporal distribution of the considered usage scenario. Also, Table 1 describes the split time intervals. Energy consumption of the machine shall be measured at input power for the following operational states (productive and non-productive modes) according to the standard [12] ISO 14955-2:2017, which requires special adaptation of the modes to the processes: drilling, boring or milling metal:

- Machine OFF: Mains are switched OFF.

- STAND BY: Mains and peripheral units are switched ON; machine control, machine processing unit and motion unit are stopped.

Note: STAND BY is an operational mode with minimum energy consumption by different parts of the machine, i.e. detectors, pumps... The unit is not operating, but there is voltage.

- READY FOR OPERATION: Mains, machine control and peripheral units are switched $\mathrm{ON}$; machine processing unit and machine motion unit are put ON HOLD.

ON HOLD mode describes the situation where the unit is switched ON but it is not operating, i.e. no processing takes place, no movements are carried out. For example, engines and control are switched $\mathrm{ON}$ and, if necessary, they would control and correct the position. (Normally, it is not necessary to correct the position because there is no movement, so energy consumption is negligible.)

- WARM UP: Mains, machine control, peripheral units and machines processing unit are switched ON but no machining takes place (MILLING HEAD is put ON HOLD), machine motion is switched ON and axes MOVING ( $2 \mathrm{~mm} / \mathrm{min})$.

- EXTENDED WARN UP: Mains, machine control, peripheral units, machines processing unit are switched ON but no machining takes place (MILLING 
HEAD is put ON HOLD), machine motion is switched ON and axes MOVING (2000 $\mathrm{mm} / \mathrm{min})$.

- PROCESSING 1: Mains, machine control, peripheral units, machine processing unit and machining (GRINDING OPERATION) are switched ON. Machine motion unit is also switched ON and axes MOVING. Cutting oil injector, chip removal and lights are switched OFF.

GRINDING OPERATION describes the operation on the previously machined bloom to achieve the desired surface finish of the workpiece. That it is to say, the machined bloom is flattened to obtain a surface finish with the allowable tolerance. Milling head works at $75 \%$.

- PROCESSING 2: Mains, machine control, peripheral units, machine processing unit and machining unit (SEMI-FINISHING OPERATIONS) are switched ON. Machine motion unit is also switched $\mathrm{ON}$ and axes MOVING. Cutting oil injector, chip removal and lights are switched OFF.

SEMI-FINISH OPERATIONS describe the operations which improve the surface quality. Milling head works at $15 \%$.

- PROCESSING 3: Mains, machine control, peripheral units, machine processing unit and machining unit (DRILLING OPERATION) are switched ON. Machine motion unit is also switched $\mathrm{ON}$ and axes MOVING. Cutting oil injector, chip removal and lights are switched OFF.

DRILLING OPERATION is used to make holes: diameter $20 \mathrm{~mm}$ and depth $60 \mathrm{~mm}$.

Furthermore, additional measurements shall be carried out, taking into account:

- Energy consumption associated with the chip conveyor

- Energy consumption associated with the cutting fluid injector

- Energy consumption associated with work lights

- Energy consumption associated with tool changes

- Energy consumption associated with milling head spins

The electrical measurements were performed at the entrance of the machine by a power analyser taking into account the measurement time and the cycle time. The distribution of electricity consumption per operational state is shown in Table 2.
Table 2 Distribution of electricity consumption in the use phase of a milling machine with horizontal ram, mobile table and numerical control (experimental measures)

\begin{tabular}{|c|c|}
\hline Mode & $\% \mathrm{kWh}$ \\
\hline Off-mode (per hour) & 0 \\
\hline Standby-mode (per hour) & 0.215 \\
\hline Ready for operation (per hour) & 1.07 \\
\hline Warm up (per hour) & 2.29 \\
\hline Extended warn up (per hour) & 3.79 \\
\hline Processing 1 (per hour) & 51.7 \\
\hline Processing 2 (per hour) & 17.7 \\
\hline Processing 3 (per hour) & 20.9 \\
\hline $\begin{array}{l}\text { Additional input associated with the chip conveyor (per } \\
\text { hour) }\end{array}$ & 0.644 \\
\hline $\begin{array}{l}\text { Additional input associated with cutting fluid injector (per } \\
\text { hour) }\end{array}$ & 1.38 \\
\hline Additional input associated with work lights (per hour) & 0.155 \\
\hline $\begin{array}{l}\text { Additional input associated with tool changes (per opera- } \\
\text { tion, } 1 \text { operation per hour) }\end{array}$ & 0.0608 \\
\hline $\begin{array}{l}\text { Additional input associated with milling head spins (per } \\
\text { operation, } 1 \text { operation per hour) }\end{array}$ & 0.0613 \\
\hline
\end{tabular}

\subsection{Environmental performance related information}

According to GPI, 2017 and the referent document [18] v2.0, the following impact categories shall be reported in the LCA-final results and EPDs: pollutant emissions as potential environmental impact (global warming, GWP, photochemical oxidant formation, POCP; acidification, AP; eutrophication, EP). The characterization factors are included in the General Programme Instructions EPD ${ }^{\circledR}$ System.

The final results of the LCA of 8 standard configurations are reported in Table 3 and 3 accessories, into the bargain. The outcomes are referred to one unit, the lifetime applied in the declared unit for the stages of the use is defined in the [18] v2.0, $16 \mathrm{~h} /$ day $\times 260$ day/year $\times 15$ years, in total $62,400 \mathrm{~h}$ of useful life.

All reconfigurations under study are covered by the same PCR and manufactured by the same company, so that they can be included in the same EPD. In addition, the different among the environmental indicators are lower than $\pm 10 \%$ (see Table 3 ), and as the result, the impact of $\mathrm{X}_{1}+\mathrm{YZ}_{2}$ is taken as reference product because its value is closer to the central number of impact for each impact category. Following the inclusion rules outlined in the GPI (2017).

The LCA results (Fig. 4) show that the contribution of downstream processes is the most significant in all studied impact categories, since the relative contributions are: $89 \%$ in the GWP and AP categories and $77 \%$ in 
Table 3 LCIA outcomes per standard configuration and accessories

\begin{tabular}{|c|c|c|c|c|}
\hline & $\begin{array}{l}\text { Global Warming, } \\
\text { GWP }\end{array}$ & $\begin{array}{l}\text { Photochemical oxidant } \\
\text { formation, POCP }\end{array}$ & Acidification, AP & Eutrophication, EP \\
\hline & $\mathrm{kg} \mathrm{CO} \mathrm{Ceq}_{\mathrm{e}}$ & $\mathrm{kg} \mathrm{C}_{2} \mathrm{H}_{4 \mathrm{eq}}$ & $\mathrm{kg} \mathrm{SO}_{2 \text { eq }}$ & $\mathrm{kg} \mathrm{PO}_{4 \mathrm{eq}}$ \\
\hline \multicolumn{5}{|c|}{ Standard configuration } \\
\hline$X_{1}+Y Z_{1}$ & 480000 & 116 & 2410 & 240 \\
\hline$X_{2}+Y Z_{1}$ & 480000 & 117 & 2420 & 239 \\
\hline$X_{3}+Y Z_{1}$ & 486000 & 120 & 2450 & 243 \\
\hline$X_{4}+Y Z_{1}$ & 494000 & 123 & 2470 & 248 \\
\hline$X_{1}+Y Z_{2}$ & 486000 & 118 & 2470 & 256 \\
\hline$X_{2}+Y Z_{2}$ & 489000 & 120 & 2460 & 258 \\
\hline$X_{3}+Y Z_{2}$ & 495000 & 123 & 2480 & 261 \\
\hline$X_{4}+Y Z_{2}$ & 500000 & 126 & 2510 & 263 \\
\hline \multicolumn{5}{|c|}{ Accessories } \\
\hline $\mathrm{ACS}_{1}$ & 5380 & 1.88 & 34.6 & 12.2 \\
\hline $\mathrm{ACS}_{2}$ & 2460 & 1.03 & 14.8 & 1.80 \\
\hline $\mathrm{ACS}_{3}$ & 8480 & 1.82 & 46.0 & 4.13 \\
\hline
\end{tabular}

Fig. 4 Environmental contribution of each life cycle stage of the range of milling machines with horizontal ram, mobile table and numerical control. Lifetime assumed: 15 years, shift pattern assumed: 2 shifts/ day, 260 days/year, $4160 \mathrm{~h}$ operational time per year (global warming, GWP; ozone depletion, ODP, photochemical oxidant formation, POCP; acidification, AP; eutrophication, EP)

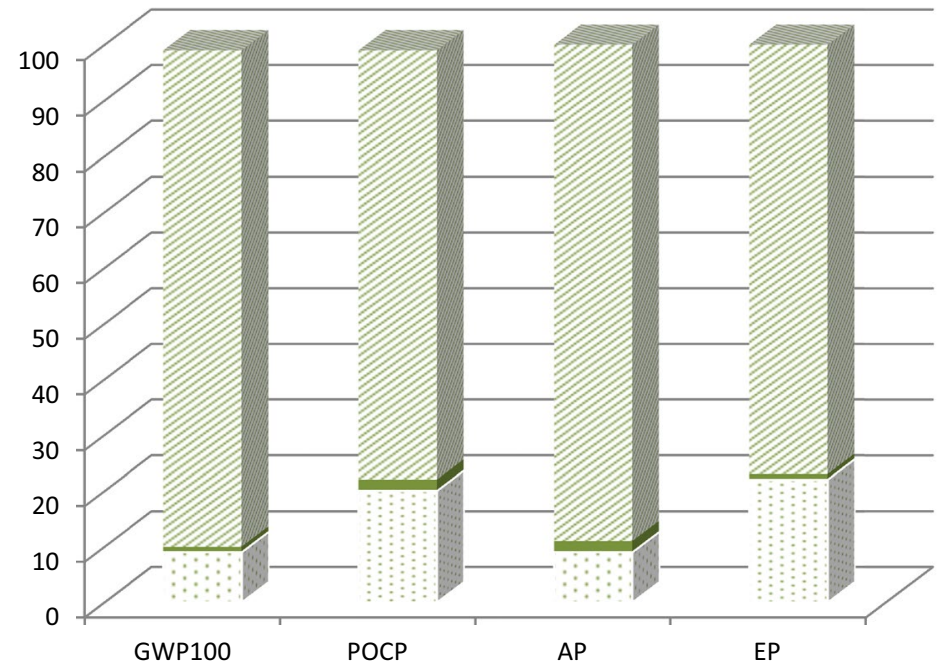

Downstream processes

- Core processes

Upstream processes the POCP and EP categories, because of the demanded electricity during the lifetime of the machines, with values greater than $94 \%$ of the impact of downstream processes. Table 2 shows that the operational process which demands more electricity is grinding process, when the previously machined bloom has achieved the desire surface finish with the allowable tolerance. However, the contribution (kWh) of several machining in the whole use phase is higher than grinding process because the share time of this process is $21 \%$ versus $10 \%$.

The upstream processes present a moderate contribution in the POCP and EP categories, being their relative contribution major than $20 \%$ in both of them, because of cast iron $(\approx 60 \%$ in POCP) and low-alloy steel $(\approx 20 \%$ in POCP) materials which form part of the structural modules as well as pumps and motors $(\approx 40 \%$ in EP).
The contribution of the core process is insignificant compared with the rest of stages; its environmental performance is below of $3 \%$ in any case.

\section{Discussion}

The study takes a holistic view of the production and consumption of a milling machine range. Technical products are very important and, at the same time, extremely difficult to evaluate due to various possible operational scenarios. A machine shall be described by its functions, which might be realized by different machine tool components (cutting, motion, control, cooling...).To overcome this limitation, a functional proposal has been descripted in the case study to ease the energy analysis, aligned the 
international standard ISO 14955-1. The estimation could be more realistic if the use phase had be assessed under 3-4 typical patter (e.g. three-shift work, one-shift work, occasional use) but this determination had overcome the effort in time and resources. Further possible developments could be still be spread out and improved in this specific way.

Life cycle thinking is a systemic framework that assesses impacts on the environment through the entire life cycle of a product/service. The system boundaries description in Fig. 3 is "cradle-to gate" type, the end of life was excluded mainly due to the difficulty in defining the end of waste state for machines tools. Machines tools are products with several lives; many products (about $80 \%$ ) are used for more than 20 years and then completely refurbished (CECIMO, 2019). In addition to around $83 \%$ of the machine is made of metallic materials, these materials are easily recyclable and can be used to produce new product again with no loss of quality. The waste management scenario would affect final results under potential benefits, due to recycling quotas.

From the fabricator perspective, a global electricity profile is applied in the use phase which represents inventories for electricity supply in all globally important economies, in line with its broad client's portfolio. From the user perspective, an electric production profile specific for the country shall be taken account.

\section{Conclusions}

Improved sustainability performance must be achieved by building and strengthening new relationships and dynamics between players along the supply chain and creating more comprehensive information relevant to environmental implications.

This paper presents the adaptation of LCA methodology for a range to milling machines, in order to develop the EPD of these products.

The multiple environmental assessment of a range of machines is achieved under information modules, thus reducing time efforts and costs. The assembly of LCA inventories and LCA assessments allowed complete the inventory or impact assessment of each final product, analysed as case study.

Although the production process of machine tools is very complex, current manufacturing processes are mostly standard. Hence, the standard production processes collected in the commercial databases are likely to properly reflect the actual production process of a milling machine. The particular emphasis should be placed on the structural parts made of cast iron and low carbon steel which present a higher environmental load in upstream processes.
The weakness of the representative check is located in the inventory analysis of the use stage. Particular efforts will be needed to ensure the effect of different types of user behaviour or different manufacturing strategies during the use phase.

In the frame of this study, the cumulative time diagram included in [18] v2.0 is used to characterise a "typical" use patter, represented a great support. Furthermore, experimental measurements of electricity consumption are made to provide a use phase scenario in close relation to industrial application (productivity, availability and/or accuracy). The achieved results from experimental measures are intended to contribute to the establishment of a set of general applications. For this reason, the test procedure is applied being machined workpieces, taking into account their properties such as hard and soft material, different cutting tools: 100 and $63 \mathrm{~mm}$, other parameters the design of machinery as guidance systems: bearings and linear.

The methodology adaptation can be extrapolated to other machine tools, in the sense that others PCR could be conducted for other machine tools and ancillary equipment classified in Group: 442 - Machine tools and parts and accessories thereof, based on PCR Basic Module CPC44 v3.0 and developed LCA studies for the product category of interest.

Acknowledgements The study of electricity consumption in "processing modes" was supported by the Spanish Ministry of Economy and Competitiveness, in the State aid Framework for Research, Development and Innovation (RTC-2014-2365-5).

\section{Compliance with ethical standards}

Conflict of interest On behalf of all authors, the corresponding author states that there is no conflict of interest.

\section{References}

1. Arrate O, Gundi L, Bailach F (2006) Ecodiseño y el Sector de Máquinas-Herramienta. XVI Congreso de Máquinas-Herramienta y Tecnologías de Fabricación, San Sebastián, Spain (in Spanish)

2. Branker K, Jeswiet J (2012) Using a new economic model with LCA-based carbon emissions inputs for process parameter selection in machining. In: 19th CIRP international conference on life cycle engineering, Berkeley

3. Central Product Classification, Ver.2 United Nations Statistics Division http://unstats.un.org/unsd/cr/registry/regcs t.asp?Cl=25. Accessed 1 Feb 2013

4. Eguren J, Hernando J, Huidobro F, Núñez Y, Pereda L, Martínez E. (2010) La sostenibilidad como estrategia empresarial y de diferenciación de productos en el grupo Nicolás Correa. 18 Congreso de Máquinas-Herramienta y Tecnología de Fabricación, San Sebastian, Spain (in Spanish) 
5. EPD International (2017) General programme instructions for the international EPD ${ }^{\oplus}$ system.Version 3.0, dated 2017-12-11

6. Fava J, Baer S, Cooper J (2011) Green(er) poduct standar trends in North America. J Ind Ecol 15(1):9-12

7. Geerts F (2019) CECIMO Circular Economy Report

8. IHOBE, Sociedad Pública de Gestión Ambiental (2010) Guías Sectoriales de Ecodiseño Máquina-Herramienta. Bilbao, Spain (in Spanish)

9. (ISO 14025:2006) Environmental labels and declarations-type III environmental declarations- principles and procedures

10. (ISO 14040:2006) Environmental management-Life cycle assessment-Principles and framework

11. (ISO 14044:2006) Environmental management-Life cycle assessment-Requirements and guidelines

12. ISO 144955-1 Machines tools- Environmental evaluation of machine tools- Part 1: Design methodology for energy-efficient machine tools

13. Koren $Y$ et al (1999) Reconfigurable manufacturing system. CIRP Ann Manuf Technol 48:527-540

14. Krautzer F, Pamminger R, Diver C, Wimer W (2015). Assessing the environmental performance of machine tools-Case studies applying the 'LCA to go' webtool. In: The 22d CIRP conference on life cycle engineering. Procedia CIRP, vol 29, pp 502-507

15. Martínez E, Pereda L, Nuñez Y, Huidobro F, González J (2011) Life cycle assessment of design modules (MOD's), optional accessories (ACS') and milling machine families (RECONF'S) v1.1 (Not published)

16. Martínez E, Pereda L, Urquidi B, Huidobro F, Arnaiz C (2007) Aplicación del ecodiseño para el ecoetiquetado de fresadora de altas prestaciones con cabezal de giro automático. CILCA 2007 Conferência Internacional Ciclo de Vida Sao Paulo, Brazil

17. Morbidoni A, Favi C, Germani M (2011) In Proceeding of the 18th CIRP International Conference on Life Cycel Enguneering Technische Universitat Braunscheeig, May 2nd-4th

18. PCR 2012:02: Machine-tools for drilling, boring or milling metal v1.0 (2012-01-25). http://www.environdec.com/en/Produ
ct-Category-Rules/Detail/?Pcr=7945\&id=158\&epslanguage=en . Accessed 1 Feb 2013

19. Pereda L, Sánchez E (2008) La apuesta pro el ecodiseño en el sector máquina-herramienta. Deformación metálica 298:54-62 (in Spanish)

20. Schischke K, Eckhard H, Feitscher R, Wilpert P, Nissen N-F (2012) Energy-using product group analysis-lot 5 machine tools and related machinery Task 3 Report-User Requirements. Berlin, Germany

21. Schischke K, Eckhard H, Feitscher R, Wilpert P, Nissen N-F (2012) Energy-using product group analysis-lot 5 machine tools and related machinery Task 7 Report-Policy and Impact Analysis. Berlin, Germany

22. Shneor Y (2018) Reconfigurable machine tool: CNC machine for milling, grinding and polishing. Procedia Manufacturing 21(2018):221-227

23. S-P-01100 NORMA, Bed-type milling machines range milling machine range. https://www.environdec.com/Detai I/?Epd=13195. Accessed 1 Sep 2018

24. Strazza C, Del Borghi A, Blengini GA. Gallo M (2010) Definition of methodology for a sector EPD (Environmental Product Declaration): case study of the average Italian cement

25. Subramanian V, Ingwersen W, Hensler C, Collie H (2012) Comparing product category rules from different programs: learned outcome towards global alignment. Int J Life Cycle Assess 17:892-903

26. Wernet G, Bauer C, Steubing B, Reinhard J, Moreno-Ruiz E, Weidema B (2016) The ecoinvent database version 3 (part I): overview and methodology. Int J Life Cycle Assess 21(9):1218-1230. https://doi.org/10.1007/s11367-016-1087-8

Publisher's Note Springer Nature remains neutral with regard to jurisdictional claims in published maps and institutional affiliations. 